\title{
A Comparative Study of Dantashodhana Chroorna and Dantashodhana Paste after Scaling in Preventing the Recurrence of Dantasharkara (Calculus)
}

\author{
Research Article
}

\section{Makwana $D^{1^{*}}$, Vaghela $\mathrm{DB}^{2}$, Patel $\mathrm{KS}^{3}$}

\begin{abstract}
1. Post Graduate Scholar, 2. In charge Head and Associate Professor, Department of Shalakya Tantra, 3. I/C Director of IPGT \& RA,

IPGT \& RA, Gujarat Ayurved University, Jamnagar, India
\end{abstract}

\begin{abstract}
Introduction: 97.1 million Persons worldwide have Dental Calculus. Scaling is standard treatment protocol for the disease. Avoidance of oral hygiene results in recurrence. Ayurveda may be helpful in this aspect. This study was planned to compare the role of Dantashodhana Choorna and Dantashodhana paste in preventing the recurrence of 'Dantasharkara' (Dental calculus) after scaling and to compare which was more convenient drug form. Materials and Method: For this study total 30 patients were registered and randomly divided into two groups, among which all patients completed the treatment. Patients were treated with; Ultrasonic scaling followed by Dantashodhana Choorna Pratisarana in group A and Dantashodhana paste application with the soft toothbrush in other group. Profoma were filled to decide better convenient drug form. Result: statistically insignificant result was obtained on comparing effect of therapy between both groups. Most persons preferred Dantashodhana paste for long term, regular use and use in diseased condition over Choorna. Conclusion: Dantashodhana paste application and Dantashodhana Choorna are almost equally effective in preventing the recurence of 'Dantasharkara' (calculus) after scaling and to regain the gingival and dental health. Dantashodhana paste is more convenient way of oral hygiene in comparison to Choorna Pratisarana.
\end{abstract}

Keywords: Dantasharakara, Dental Calculus, Dantashodhana Choorna Pratisarana, Toothpaste, Scaling.

\section{Introduction:}

Ayurveda is a science of life and it accentuates on prevention of disease condition than cure. Guidelines for daily care of oral cavity under the heading 'Dinacharya' has been given in all texts of Ayurveda. Negligence of oral care may give rise to different oral diseases. The importance has been given to oro-dental hygiene to maintain health and beauty. The healthy teeth are very much necessary for the healthy body. Many procedures have been described for routine oral hygiene in Ayurveda like Dantadhavana, Jihvanirlekhana, Pratisarana, Gandusha, Tambula Bhakshana etc. Pratisarana is gently rubbing over teeth with the tip of a finger. There are four types of Pratisarana i.e. Kalka, Rasakriya, Madhu and Choorna Pratisaran. (1)

In Nidana Sthana, Acharya Sushruta has described the Mukharoga (diseases affecting the oral cavity). Diseases of Mukha are classified according to the seven subsites i.e. A ushta (Lips), Danta (Teeth), Dantamula (Gums), Jihwa (Tongue), Talu (Palate), Kantha (Throat) and Sarvasara (Oral cavity). (2) Dantsarkara is one among the Danta Roga.

\section{*Corresponding Author:}

\section{Dhara M. Makwana}

Post-Graduate scholar, epartment of Shalakya Tantra IPGT \& RA, Gujarat Ayurved University, Jamnagar, India.

E-mail: study.ayurved@gmail.com
Dantasharkara takes place when routine oral hygiene is not maintained. A collection of tartar at the junction of teeth and gums and in between the teeth is known as 'Dantasharkara'. The tartar is rough and hard and is often associated with halitosis. When 'Dantasharkara' is not treated at the appropriate time, Dantavalka i.e. enamel of teeth is eroded and gets detached from the teeth along with the overlying crust of tartar which is known as 'Kapalika'.(3)

According to the modern science, dental calculus is a hard deposit that forms by mineralization of dental plaque and is usually covered by a layer of unmineralized plaque. Calculus can be classified as Supra gingival and Sub gingival. (4)

Scaling is the first line of treatment for the removal of supragingival and subgingival calculus. It removes all of the irritants under the gums to eliminate inflammation and infection. Scaling is non-surgical but it is a different type of procedure from a standard dental cleaning because it involves cleaning the areas of the tooth below the gum line.

There are two types of scaling instruments: (5)

- Scaling with hand-held instruments: a dental scaler and curette are used to manually remove (scale) the plaque from the teeth.

- Scaling with ultrasonic instruments: ultrasonic scaling instruments clean plaque from the teeth with a vibrating metal tip that chips off the tartar and water spray to wash it away and keep the tip cool.

The removal of calculus by scaling is of transient benefit but it reforms again within a short period. Good oral hygiene is the best means of prevention. The 
Ayurvedic aspect of oral hygiene may be effective in prevention or recurrence of the disease. Pratisarana with Dantashodhana Choorna can be used for this purpose. But now a days, paste form is more convenient for the patients than powder form. In the present study, the toothpaste was prepared using the contents of the Dantashodhana Choorna.

\section{Aims and Objectives:}

- To assess the role of Dantashodhana Choorna and Dantashodhana paste in preventing the recurrence of dental calculus after scaling.

- To compare the efficacy of Choorna and paste form in regaining the gingival and dental health after scaling.

\section{Hypothesis:}

- Null hypothesis: Dantashodhana paste application is not better and convenient way than Dantashodhana Choorna Pratisaran in preventing the recurrence of calculus after scaling.

- Alternative hypothesis: Dantashodhana paste application is better and convenient way than Dantashodhana Choorna Pratisaran in preventing the recurrence of calculus after scaling.

\section{Selection of Patients:}

- All patients fulfilling the inclusion criteria were selected from the OPD of Shalakya Tantra Department and also referred from OPD of other departments, IPGT\&RA, Jamnagar.

- All details of the patients were recorded and maintained in the specially prepared proforma [CRFClinical Registration Format].

\section{Study Design:}

- Type of study: Randomized Parallel Group Trial.

- Grouping: Selected patients were randomly divided into two groups irrespective of age, sex, caste, religion etc.

- Randomization was done using software (Graph Pad).

- The study was started after getting ethical clearance from the institutional ethics committee.

- IEC NUMBER: PGT/7/-A/Ethics/2015-16/1490 [IEC approval on 25/08/2015],

- CTRI NUMBER: CTRI/2016/03/006731 [CTRI Registered on 17/03/2016]

\section{Inclusion Criteria:}

- Patients between the age of sixteen and sixty years.

- Patients having the calculus deposition were selected for the study.

\section{Exclusion Criteria} of age.

The Patient below 16 years and above 60 years

\section{Patient having}

Mobile teeth,

Cardiac disorder,

Blood disorder,

Respiratory disorder,

Patients who require surgical intervention.
Research Proforma:

A detailed proforma was prepared to study the Patients as well as the disease.

\section{Investigations:}

Following investigations were carried out before treatment.

Hematological investigation - TLC, DLC,

$\mathrm{Hb} \%$, ESR, BT, CT

Urine Routine \& microscopic investigation

Grouping of patients:

- Group A - In this group patients were administered Ultrasonic scaling followed by Dantashodhana Choorna Pratisarana and routine oral hygiene.

- Group B - In this group patients were administered Ultrasonic scaling followed by Dantashodhana paste application with the soft toothbrush and routine oral hygiene.

Drug and posology:

Group A:

Drug: Dantashodhana Choorna (Table-1)

Dose: 1 gm twice a day for Pratisarana with honey and Tila Taila for Pratisarana (Local massage over teeth and gums)

Time: 100-200 Matra Kala (2-4 min. approx.)

Duration: 30 days

Group B:

Drug: Dantashodhana Paste (Table-2)

Dose: Dantashodhana Paste application: 2 applications twice a day with soft toothbrush.

Time: $2 \mathrm{~min}$.

Duration: 30 days

Proper brushing method and its importance were explained to the patients of both groups.

Follow up: After completion of the treatment, the patients were followed for one month at the interval of fifteen days.

Criteria for the Assessment:

- Assessment was done on the basis of Oral Hygiene Index (OHI) (Table-5) and Gingival Index (GI) (Table-6).

- OHI (Table-5) = CI (Calculus Index) +DI (Debris Index) (Table-3, Table-4)

- Improvement in the subjective complaints was also assessed. (Table-7, Table-8, Table-9, Table-10)

\section{Assessment of Total Effect of Therapy:}

The total effect of therapy was assessed on the basis of subjective and objective criteria and patients were grouped into following five steps.

- Complete relief: $100 \%$ relief in subjective and objective signs and symptoms.

- Marked relief: Above 76-100\% relief in subjective and objective signs and symptoms.

- Moderate relief: $51-75 \%$ relief in subjective and objective signs and symptoms.

- Mild relief: 26-50\% relief in subjective and objective signs and symptoms.

- No relief: Below 25\% relief in subjective and objective signs and symptoms. 
Statistical Analysis:

The information gathered on the basis of above observations was subjected to statistical analysis in terms of mean(x), standard deviation (S.D.) and standard error (S.E.) Paired ' $\mathrm{t}$ 'test was carried out at $\mathrm{P}<0.05, \mathrm{P}<0.01$ and $\mathrm{P}<0.001$ levels. The results obtained are considered highly significant for $\mathrm{p}<0.001$, significant for $\mathrm{p}<0.01$, $\mathrm{p}<0.05$, and insignificant for $\mathrm{p}>0.05$.

\section{Observations and Results:}

For this study total 30 patients were registered and randomly divided into two groups, among which all patients completed the treatment.

Age:-

A maximum number of the patients i.e. $56.67 \%$ belonged to the age group of $16-30$ years. $26.66 \%$ of the patients belonged to $31-40$ years.

\section{Gender:-}

The majority of the patients were female i.e. $83.33 \%$ most of them were house wives.

\section{Aaharajanya Nidana:}

Maximum patients i.e. $93.33 \%$ were having Madhura Amla Lavan Rasa (excessive use) as Nidana for Dantasarakara. $56.66 \%$ patients were taking Guru Aahara $70 \% \%$ of patients were taking Dugdha daily while $63.33 \%$ of patients were taking Dadhi. $70 \%$ of the patients were eating sticky chocolates. $66.66 \%$ of the patients were using packed \& processed food as Nidana for Dantasarakara. (Table-11)

\section{Viharajanya Nidana:}

$83.33 \%$ of the patients were doing wrong way of tooth brushing. Dantadhavandvesha was observed in $43.33 \%$ of the patients and improper mouthwash was observed in $16.66 \%$ of the patients. (Table-12)

\section{Chief complain}

All the patients were having inflammation of gums as their chief complaint. $86.66 \%$ of the patients were having halitosis while $73.33 \%$ of the patients were having bleeding gums and pain. (Table-13)

\section{Teeth Examination:}

All the patients were having calculus deposition over their teeth. $76.66 \%$ of the patients were having pain in teeth along with calculus deposition. Malocclusion was observed in $40 \%$ of the patients. Carious teeth were observed in $36.66 \%$ of the patients. Sensitivity was present in rest of the patients. (Table-14)

\section{Gingival Examination:}

All patients having calculus deposition were also suffering from inflammation of gums followed by $76.66 \%$ of the patients having bleeding gums. $80 \%$ of the patients were having the abnormal color of gingiva. (Table-15)

\section{Effect of therapy on signs and symptoms Group-A.}

$60 \%$ relief was observed in pain which was statistically significant at the level of $p<0.01 .66 .66 \%$ relief was observed in inflammation of gums which was statistically highly significant at the level of $\mathrm{p}<0.001$. 56.67\% relief was observed in bleeding gums which was statistically highly significant at the level of $\mathrm{p}<0.001 .73 .33 \%$ relief was observed in halitosis which was statistically highly significant at the level of $\mathrm{p}<0.001$. (Table-16)

\section{Effect of therapy on signs and symptoms Group- B.}

$100 \%$ relief was observed in pain which was statistically highly significant at the level of $p<0.001$. $93.33 \%$ relief was observed in inflammation of gums which was statistically highly significant at the level of $p<0.001 .80 \%$ relief was observed in bleeding gums which was statistically highly significant at the level of $\mathrm{p}<0.001$. $90 \%$ relief was observed in halitosis which was statistically highly significant at the level of $p<0.001$. (Table-17)

\section{Effect of therapy on Objective criteria Group-A.} $80 \%$ improvement was observed in Calculus Index which was statistically highly significant at the level of $\mathrm{p}<0.001$. $73.33 \%$ improvement was observed in Debris Index which was statistically highly significant at the level of $p<0.001 .83 .33 \%$ improvement was observed in Oral Hygiene Index which was statistically highly significant at the level of $\mathrm{p}<0.001$. 66.66\% improvement was observed in Gingival Index which was statistically highly significant at the level of $p<0.001$. (Table-18)

\section{Effect of therapy on Objective criteria Group-B.}

$100 \%$ improvement was observed in Calculus Index which was statistically highly significant at the level of $p<0.001$. $96.66 \%$ improvement was observed in Debris Index which was statistically highly significant at the level of $p<0.001 .100 \%$ improvement was observed in Oral Hygiene Index which was statistically highly significant at the level of $p<0.001 .93 .33 \%$ improvement was observed in Gingival Index which was statistically highly significant at the level of $p<0.001$. (Table-19)

\section{Comparison of the effect of therapy on subjective criteria}

Statistically, no significant difference was found between two groups in effect on subjective parameters. (Table-20) (Figure 1)

\section{Comparison of the effect of therapy on objective criteria}

Statistically, no significant difference was observed in the context of objective criteria like Debris Index, Oral Hygiene Index, Gingival Index unless calculus index $(<0.001)$. (Table-21) (Figure 2)

\section{Overall assessment of therapy of therapy}

Out of 15 Patients of group-A, none of the patients was cured, $40 \%$ of the patients showed 
marked improvement and moderate improvement. $13.33 \%$ of patients showed mild improvement. $6.66 \%$ of the patients remained unchanged. In group-B, $60 \%$ of the patients were cured. $33.33 \%$ showed marked improvement while $6.67 \%$ showed moderate improvement. None of the patients showed mild improvement or remained unchanged. (Table-22) (Figure 3)

\section{ADR (Adverse Drug Reaction):}

No ADR was reported during the trial period and follow up.

\section{Feedback}

Feedback form contained 13 questions regarding color, taste, preference for regular use and in disease conditions etc. of paste and Pratisarana Feedback forms were filled up by subjects $(n=20)$ who had completed treatment and with good OHI score or healthy volunteers. (Table-23)

\section{Discussion:}

Age:

Patients between the age group of 16-60 years were selected for the present study Maximum number of the patients i.e. $56.67 \%$ belonged to the age group of 16-30 years. The studies have shown that the incidence of calculus increases during 16-30 years. (6) As most of the people are not aware of dental diseases because usually, they are painless in the early stages, it can be believed that cosmetically more concerned people in this age group marked changes in their teeth and gingiva.

\section{Gender:}

The majority of the patients were female i.e. $83.33 \%$ most of them were house wives this may be contributed to their ignorance for routine oral hygiene due to household activities.

\section{Nidana:}

93.33\% of patients were taking Madhura Rasa dominant diet followed by $66.66 \%$ of patients taking Lavana Rasa. Amla Rasa dominancy was found in $46.66 \%$ of the patients. Excessive intake of Madhura, Amla, Lavana Rasa leads to increased Kapha, which plays an important role in the pathogenesis of Disease. $70 \%$ of patients were taking Snigdha Guna dominant diet followed by $56.66 \%$ of patients taking Guru Guna dominant diet. Sheeta Guna dominancy was observed in $43.33 \%$ of patients. Excessive intake of Snigdha and Guru Guna leads to increased Kapha, one of the culprits in disease pathology. $83.33 \%$ of the patients were doing wrong way of tooth brushing. Dantadhavandvesha was observed in $43.33 \%$ of the patients. Due to Lack of oral hygiene formation of plaque occurs which leads to calculus. (7)

\section{Chief complaint:-}

All the patients were having inflammation of gums as their chief complaint. $86.66 \%$ of the patients were having halitosis while $73.33 \%$ of the patients were having bleeding gums and pain.
Inflammation is the result of physical irritation of gums and presence of bacterial toxic by-products in the calculus. There is always a positive correlation between the calculus and prevalence of gingivitis. (8)

\section{Teeth examination:-}

All the patients were having calculus deposition over their teeth. $76.66 \%$ of the patients were having pain in teeth along with calculus deposition. Malocclusion was observed in $40 \%$ of the patients. Carious teeth were observed in $36.66 \%$ of the patients. Sensitivity was present in rest of the patients.

Studies showed that calculus status was not significantly associated with caries, but there was a high association between gingivitis and plaque status with calculus accumulation. (9)

\section{Gingival Examination:-}

All patients having calculus deposition were also suffering from inflammation of gums followed by $76.66 \%$ were having bleeding gums. $80 \%$ of the patients were having the abnormal color of gingiva.

As dental calculus builds, it starts to creep under the gums and attack the surrounding tissue. The eventual result is gum disease, which can lead to tooth loss if not treated. (10)

\section{Effect of therapies on signs and symptoms: Effect of therapies on Pain:}

In group-A, $60 \%(\mathrm{p}=0.638)$ relief was observed in pain which was statistically significant. The pain was $100 \%(p<0.001)$ relieved in group-B patients which were statistically highly significant.

\section{Effect of Therapies on inflammation of gums:}

Inflammation of gums was $66.66 \%(\mathrm{p}<0.001)$ relieved in group-A, while in group-B, $93.33 \%$ $(p<0.001)$ relief was observed which was statistically highly significant.

\section{Effect of Therapies on bleeding:}

In group- $A, \quad 56.67 \% \quad(\mathrm{p}<0.001)$ relief was observed in bleeding, while in group-B, $80 \%(p<0.001)$ relief was observed which was statistically highly significant.

\section{Effect of therapies on halitosis:}

In group- $A, \quad 73.33 \% \quad(p<0.001)$ relief was observed in halitosis, while in group-B, $90 \%(p<0.001)$ relief was observed which was statistically highly significant.

\section{Effect of therapies on Calculus Index:}

While comparing the improvement in Calculus index in both the study groups, Group A showed $80 \%$ $(p<0.001)$ improvement of this index followed by Group B patients who showed improvement of calculus index $100 \% \quad(p<0.001)$. The improvement was statistically highly significant in both groups.

\section{Effect of therapies on Debris Index:}

Group A showed 73.33\% $\quad(\mathrm{p}<0.001)$


improvement in debris index, while Group B patients showed improvement in debris index up to $96.66 \%$ $(\mathrm{p}<0.001)$. The improvement was statistically highly significant in both groups.

\section{Effect of therapies on OHI (Oral Hygiene Index):}

Group A showed 83.33\% $\quad(p<0.001)$ improvement in $\mathrm{OHI}$, while Group B patients showed improvement in OHI up to $100 \% \quad(\mathrm{p}<0.001)$. Improvement was statistically highly significant in both groups.

\section{Effect of therapies on Gingival Index:}

Highly significant improvement in gingival index was observed among Group A patients (66.66\%, p < $0.001)$ and Group B patients $(93.33 \%, \mathrm{p}<0.001)$.

\section{Comparison of effect of the therapy on subjective criteria:}

Data illustrates that results obtained in subjective criteria like Inflammation of gums, Halitosis, Bleeding gums, Pain etc., statistically insignificant result was obtained between both groups.

\section{Comparison of effect of the therapy on objective criteria:}

Data of present study which can be interpreted that On comparison of effect between both groups, statistically no significant difference was observed in objective criteria like Debris Index, Oral Hygiene Index, Gingival Index unless calculus index $(<0.001)$. In Calculus Index highly significant difference was observed.

\section{Overall assessment of the therapy of therapy:}

Out of 15 Patients of group-A, none of the patients were noted cured, $40 \%$ showed marked improvement and $40 \%$ showed moderate improvement. $13.33 \%$ of the patients showed mild improvement. $6.66 \%$ of the patients were noted unchanged.Out of 15 Patients of group-B, $60 \%$ of the patients were noted cured. $33.33 \%$ showed marked improvement, $6.66 \%$ showed moderate improvement. None of the patients noted mild improvement and unchanged.

\section{Probable mode of action of pratisarana:}

Pratisarana mainly possesses two types of therapeutic efficacy by rubbing with finger locally.

1. Shodhana (Mechanical removal of food particles, plaque, and calculus).

2. Massage

\section{Mechanical removal of food particles:}

By Pratisarana mechanical pressure is exerted on gums in the direction of the gingival sulcus which remove food debris, plaque some part of calculus too. By pressure, it clears sticky bio-film on tooth surface which is responsible for growing micro-organism.

\section{Massage:}

Due to gingival massage during Pratisarana gingival epithelial cells are stimulated which lead to regeneration of the gingiva thus helping in keratinization and this process may help in retarding the inflammation at vascular, cellular and immune level. It may increase the defence mechanism of gingiva.

\section{Probable mode of action of Dantashodhana Choorna:}

Dantashodhana Choorna was taken as medicine for Pratisrana in the prevention of Dantasharakara (Dental Calculus) in the current study. (11) Compositions of Dantashodhana Choorna are Vyosha (Shunthi, Marich, Pippali), Trivarg (Twak, Ela, Tamalapatra), Tejovti and Saindhava.

Shunthi has Katu Rasa, Laghu Singdha Guna, Ushna Virya, Vatakaphashamak properties. Katu Rasa, Laghu Ruksha Guna, Ushna Virya, Katu Vipaka, Vatakaphashamak properties are in Marich. Pippali has Katu Rasa, Laghu, Tikshna and Singdha Guna, Anushna Virya, Vatakaphashamak properties. Properties of Twak are like Katu, Tikta, Madhur Rasa, Laghu, Tikshna, Ruksha Guna, Ushna Virya, Katu Vipaka, and Vatakaphashamak. Ela has Katu, Madhura Rasa, Laghu Ruksha Guna, Trodoshshamaka properties. Katu, Madhura Rasa, Laghu, Tikshna, Pichchila Guna, Ushna Virya, Katu Vipaka, Vatakaphashamak properties are in Tamalapatra.(12) Properties of Tejovati are like Katu, Tikta Rasa, Ruksha Guna, Ushna Virya, Katu Vipaka, Vatashamak etc.(13) Saindhava has Tridoshakshamaka, Ushan Virya, Laghu, Ruksha, Sukshma Guna Properties.

Thus the drug Dantashodhana Choorna is seen to be predominantly Katu (100\%) Rasa; Laghu (85.71\%), Tikshna (57.14\%), Ruksha (42.85\%) Guna; Ushna (71.43\%) Virya; Katu (57.14\%) Vipaka and VaatKaphashamaka $(85.71 \%)$.

Katu Rasa act as Shodhana, Lekhana, Kleda Shoshaka, Vrananasaka, Krimighna and Kaphanashak. Acharya Charak has described Katu Rasa as Vaktra Shodhaka.(14) Laghu-Ruksha-Tikshna Guna are Kaphashamaka. Ushna Virya exhibits VataKaphashamaka activities. Katu Vipaka normalizes vitiated Kapha. Saindhava has Properties of Rochana, Deepana, tridodhghana (15) Ladhu, Agnideepana. (16)

With these properties, it not only prevents plaque formation but also helps in curing associated infection and inflammation of gums. The majority of drugs are having Deepana and Pachana properties which help to reduce local Mala. Tail Tail and Honey were increased efficacy of Dantashodhana Choorna.

\section{Probable mode of action of Dantashodhana Paste with soft tooth brush:}

Contents of Dantasodhana paste are same as Dantasodhana Choorna with the common base of paste but not including Madhu and Tila Taila. Application of Dantashodhana Paste should be done with the soft tooth brush and proper method. Gentle massage gives Mechanical Pressure on gingival sulcus and gingiva that remove food particles and Sticky biofilm of plaque. 
Paste have Anti-Bacterial (S. aureus) and Anti-Fungal (Candida albicans) properties, So Anti-Microbial activities of Dantasodhana paste can prevent recurrent infection and ultimately that leads to reduced formation of Dental Calculus.

Application of Dantashodhana Paste stops the growth of dental plaque and bacteria by reducing the amount of acid produced. This stops the bacteria from producing dextran (gummy polysaccharide), which adhere to the surface of teeth and produce dental plaque. The base material for tooth paste helps in quick absorption of other ingredients.

\section{Conclusion:}

From the results and observation which were received from this study, it can be concluded that Dantashodhana paste (Group B) application and Dantashodhana Choorna (Group A) are almost equally effective (Statistically) in preventing the recurrence of 'Dantasharkara' (calculus) after scaling and to regain the gingival and dental health.

From observation which was received from specially prepared feedback form, it can be concluded Dantashodhana paste is the more convenient way of oral hygiene in comparison to Dantashodhana Choorna Pratisarana.

Table - 1: Composition of Dantashodhana Choorna: (17)

\begin{tabular}{|l|l|l|c|}
\hline $\begin{array}{c}\text { Sr. } \\
\text { No. }\end{array}$ & Name & \multicolumn{1}{|c|}{$\begin{array}{c}\text { Botanical / } \\
\text { English name }\end{array}$} & Proportion \\
\hline 1 & $\begin{array}{l}\text { Vyosha } \\
\text { Shunthi } \\
\text { Maricha } \\
\text { Pippali }\end{array}$ & $\begin{array}{l}\text { Zingiber officinale } \\
\text { Rosc. } \\
\text { Piper nigrum } \\
\text { Linn. } \\
\text { Piper longum } \\
\text { Linn. }\end{array}$ & 1 part \\
\hline 2 & $\begin{array}{l}\text { Trivarga } \\
\text { Twaka } \\
\text { Ela } \\
\text { Tamala } \\
\text { zeylanica } \text { Bl. } \\
\text { Elettaria } \\
\text { cardamomum } \\
\text { Maton. } \\
\text { Cinnamomum } \\
\text { tamala } \text { Nees. }\end{array}$ & 1 part \\
\hline 3 & Tejovati & $\begin{array}{l}\text { Zanthoxylum } \\
\text { armetum DC. }\end{array}$ & 1 part \\
\hline 4 & Saindhava & Rock salt & 1 part \\
\hline 5 & Madhu & Honey & Q.S. \\
\hline 6 & Tila taila & Sesame oil & Q.S. \\
\hline
\end{tabular}

Table 2: Ingredients of Dantashodhana Paste:

\begin{tabular}{|l|l|l|}
\hline No. & Name & Percentage \\
\hline 1 & Dantashodhana Ghana & $27 \%$ \\
\hline 2 & Dantashodhana Kwatha & $18 \%$ \\
\hline 3 & Saindhav & $7.20 \%$ \\
\hline 4 & Glycerin & $12.60 \%$ \\
\hline 5 & Sorbitol & $12.60 \%$ \\
\hline 6 & CMC & $1.26 \%$ \\
\hline 7 & SLS & $3.24 \%$ \\
\hline
\end{tabular}

\begin{tabular}{|l|l|l|}
\hline No. & Name & Percentage \\
\hline 8 & Calcium Carbonate & $18 \%$ \\
\hline 9 & Methylparaben & $0.02 \%$ \\
\hline 10 & Propylparaben & $0.02 \%$ \\
\hline 11 & Saccharine & $0.06 \%$ \\
\hline 12 & Peppermint oil & $0.5 \%$ \\
\hline
\end{tabular}

Table-3: Calculus Index (CI):

\begin{tabular}{|l|l|}
\hline Score & Criteria \\
\hline 0 & No calculus present \\
\hline 1 & $\begin{array}{l}\text { Supragingival calculus covering not more } \\
\text { than one third of the exposed tooth surface }\end{array}$ \\
\hline 2 & $\begin{array}{l}\text { Supragingival calculus covering more than } \\
\text { one third but not more than two thirds of the } \\
\text { exposed tooth surface or the presence of } \\
\text { individual flecks of subgingival calculus } \\
\text { around the cervical portion of the tooth or } \\
\text { both. }\end{array}$ \\
\hline 3 & $\begin{array}{l}\text { Supragingival calculus covering more than } \\
\text { two thirds of the exposed tooth surface or a } \\
\text { continuous heavy band of subgingival cal- } \\
\text { culus around the cervical portion of the } \\
\text { tooth or both. }\end{array}$ \\
\hline
\end{tabular}

Table-4: Debris Index (DI):

\begin{tabular}{|l|l|}
\hline Score & Criteria \\
\hline 0 & No debris or stain present \\
\hline 1 & $\begin{array}{l}\text { Soft debris covering not more than one third } \\
\text { of the tooth surface or the presence of ex- } \\
\text { trinsic stains without other debris regardless } \\
\text { of surface area covered }\end{array}$ \\
\hline 2 & $\begin{array}{l}\text { Soft debris covering more than one third, } \\
\text { but not more than two thirds of the exposed } \\
\text { tooth surface. }\end{array}$ \\
\hline 3 & $\begin{array}{l}\text { Soft debris covering more than two thirds of } \\
\text { the exposed tooth surface. }\end{array}$ \\
\hline
\end{tabular}

Table-5: Oral Hygiene Index (OHI):

\begin{tabular}{|c|c|c|}
\hline Score & Criteria & Inference \\
\hline 0 & Score $0.0-1.2$ & Good \\
\hline 1 & Score $1.3-3.0$ & Fair \\
\hline 2 & Score $3.1-6.0$ & Poor \\
\hline
\end{tabular}

\section{Table-6: Gingival Index}

\begin{tabular}{|l|l|}
\hline Score & Criteria \\
\hline 0 & Absence of inflammation/ Normal gingival \\
\hline 1 & $\begin{array}{l}\text { Mild inflammation; slight change in color, } \\
\text { slight oedema; no bleeding on probing. }\end{array}$ \\
\hline 2 & $\begin{array}{l}\text { Moderate inflammation; redness, oedema, } \\
\text { moderate glazing, hypertrophy. Bleeding } \\
\text { on probing }\end{array}$ \\
\hline 3 & $\begin{array}{l}\text { Severe inflammation; marked redness, } \\
\text { oedema and hypertrophy, ulceration. } \\
\text { Tendency to spontaneous bleeding. }\end{array}$ \\
\hline
\end{tabular}


Table-7: Pain

\begin{tabular}{|l|l|}
\hline Score & Criteria \\
\hline 0 & No pain \\
\hline 1 & Occasional pain with low intensity \\
\hline 2 & Frequent pain with moderate intensity \\
\hline 3 & $\begin{array}{l}\text { Continuous pain with severe intensity } \\
\text { which increases during mastication }\end{array}$ \\
\hline
\end{tabular}

Table-8: Inflammation of gums

\begin{tabular}{|l|l|}
\hline Score & Criteria \\
\hline 0 & Absence of inflammation \\
\hline 1 & $\begin{array}{l}\text { Mild inflammation, slight change in color } \\
\text { and in texture of the marginal or papillary } \\
\text { gingival unit. }\end{array}$ \\
\hline 2 & $\begin{array}{l}\text { Moderate inflammation, glazing redness, } \\
\text { edema of the marginal or papillary gingival } \\
\text { unit. }\end{array}$ \\
\hline 3 & $\begin{array}{l}\text { Severe inflammation, marked redness, ede- } \\
\text { ma of the marginal or papillary gingival } \\
\text { unit. }\end{array}$ \\
\hline
\end{tabular}

Table-9: Bleeding gums

\begin{tabular}{|l|l|}
\hline Score & Criteria \\
\hline 0 & No bleeding \\
\hline 1 & Bleeding point appears on probing \\
\hline 2 & $\begin{array}{l}\text { Several isolated bleeding points or a single } \\
\text { fine line of blood appears. }\end{array}$ \\
\hline 3 & $\begin{array}{l}\text { The interdental triangle fills with blood } \\
\text { shortly after probing. }\end{array}$ \\
\hline 4 & $\begin{array}{l}\text { Profuse bleeding occurs after probing; } \\
\text { blood flows immediately into the marginal } \\
\text { sulcus. }\end{array}$ \\
\hline
\end{tabular}

Table-10: Halitosis

\begin{tabular}{|l|l|}
\hline Score & Criteria \\
\hline 0 & Absence of bad odour \\
\hline 1 & Presence of mild bad odour \\
\hline 2 & Presence of severe bad odour \\
\hline
\end{tabular}

Table-11: Aaharajanya Nidana wise distribution of patients $(\mathrm{n}=30)$.

\begin{tabular}{|l|c|c|c|c|}
\hline Aaharajanya Nidana & GroupA & Group B & Total & \% \\
\hline Madhura Amla Lavan Rasa & 15 & 13 & 28 & 93.33 \\
\hline Alpa Pramita Ruksha Sevana & 5 & 6 & 11 & 36.66 \\
\hline Usna Vidahi Aahara Sevana & 9 & 4 & 13 & 43.33 \\
\hline Matsya Sevana & 2 & 1 & 3 & 10 \\
\hline Guru Aahara & 10 & 7 & 17 & 56.66 \\
\hline Dugdha & 11 & 10 & 21 & 70 \\
\hline Dadhi & 9 & 10 & 19 & 63.33 \\
\hline IkshuRasa & 5 & 6 & 11 & 36.33 \\
\hline Packed \& processed food & 9 & 11 & 20 & 66.66 \\
\hline Sticky chocolates & 10 & 11 & 21 & 70 \\
\hline Pastry & 6 & 9 & 15 & 50 \\
\hline
\end{tabular}

Table-12: Viharajanya Nidana wise Distribution of patients $(n=30)$.

\begin{tabular}{|l|c|c|c|c|}
\hline Viharajanya Nidana & Group A & Group B & Total & \% \\
\hline Dantadhavanadvesh & 9 & 4 & 13 & 43.33 \\
\hline Wrong way of tooth brushing & 14 & 11 & 25 & 83.33 \\
\hline Improper mouthwash & 3 & 2 & 5 & 16.66 \\
\hline Mouth breathing & 2 & 2 & 4 & 13.33 \\
\hline
\end{tabular}

Table-13: Chief Complains wise distribution of patients $(n=30)$.

\begin{tabular}{|l|c|c|c|c|}
\hline Chief Complain & Group A & Group B & Total & \% \\
\hline Inflammation of gums & 15 & 15 & 23 & 100 \\
\hline Bleeding & 10 & 13 & 27 & 86.66 \\
\hline Halitosis & 13 & 14 & 23 & 73.33 \\
\hline Pain & 9 & 14 & & 73.33 \\
\hline
\end{tabular}


International Journal of Ayurvedic Medicine, 2017, 8(2), 80-91

Table-14: Teeth Examination wise distribution of patients $(n=30)$.

\begin{tabular}{|l|c|c|c|c|c|}
\hline Examination of Teeth & & Group-A & Group-B & Total & \% \\
\hline Tartar Deposition & Present & 15 & 15 & 30 & 100 \\
\cline { 2 - 6 } & Absent & 0 & 0 & 0 & 0 \\
\hline Carious Teeth & Absent & 6 & 5 & 11 & 36.66 \\
\cline { 2 - 6 } & Absent & 9 & 10 & 19 & 63.33 \\
\hline \multirow{2}{*}{ Oensitivity } & Absent & 3 & 0 & 3 & 10 \\
\cline { 2 - 6 } & Absent & 12 & 15 & 27 & 90 \\
& $\begin{array}{c}\text { Absent } \\
\text { (Malocclusion) }\end{array}$ & 8 & 4 & 12 & 40 \\
\cline { 2 - 6 } & $\begin{array}{c}\text { Absent } \\
\text { (Normal) }\end{array}$ & 7 & 11 & 18 & 60 \\
\hline Pain & Absent & 9 & 14 & 23 & 76.66 \\
\cline { 2 - 6 } & Absent & 6 & 1 & 7 & 23.33 \\
\hline
\end{tabular}

Table-15: Gingival Examination wise distribution of patients $(n=30)$.

\begin{tabular}{|l|l|c|c|c|c|}
\hline Gingival Examination & Group-A & Group-B & Total & \% \\
\hline \multirow{2}{*}{ Color } & Normal & 4 & 2 & 6 & $20 \%$ \\
\cline { 2 - 6 } & Abnormal & 11 & 13 & 24 & $80 \%$ \\
\hline \multirow{2}{*}{$\begin{array}{l}\text { Inflammation of } \\
\text { gums }\end{array}$} & Present & 15 & 15 & 30 & $100 \%$ \\
\cline { 2 - 6 } & Absent & 0 & 0 & 0 & $0 \%$ \\
\hline \multirow{2}{*}{ Bleeding gums } & Present & 10 & 13 & 23 & $76.66 \%$ \\
\cline { 2 - 6 } & Absent & 5 & 2 & 7 & $23.33 \%$ \\
\hline
\end{tabular}

Table-16: Effect of therapy on signs and symptoms Group-A.

\begin{tabular}{|c|c|c|c|c|c|c|c|c|c|c|}
\hline \multirow{2}{*}{ Complain } & \multirow{2}{*}{$\mathbf{N}$} & \multicolumn{2}{|c|}{ Mean } & \multirow{2}{*}{$\begin{array}{c}\text { Mean } \\
\text { diff. }\end{array}$} & \multirow{2}{*}{$\%$ Relief } & \multirow{2}{*}{ SD } & \multirow{2}{*}{ SE } & \multirow{2}{*}{ ' $t$ ' } & \multirow{2}{*}{$\mathbf{P}$} & \multirow{2}{*}{ Si. } \\
\hline & & BT & AT & & & & & & & \\
\hline Pain & 9 & 0.667 & 0.067 & 0.600 & $60 \%$ & 0.828 & 0.214 & 2.806 & $<0.01$ & $S$ \\
\hline Inflammation & 15 & 1.467 & 0.333 & 1.133 & $66.66 \%$ & 0.743 & 0.192 & 5.906 & $<0.001$ & HS \\
\hline Bleeding & 10 & 0.800 & 1.333 & 0.667 & $56.67 \%$ & 0.617 & 0.159 & 4.183 & $<0.001$ & HS \\
\hline Halitosis & 13 & 1.467 & 0.200 & 1.267 & $73.33 \%$ & 0.799 & 0.206 & 6.141 & $<0.001$ & $\mathrm{HS}$ \\
\hline
\end{tabular}

Table-17: Effect of therapy on signs and symptoms Group-B.

\begin{tabular}{|c|c|c|c|c|c|c|c|c|c|c|}
\hline \multirow{2}{*}{ Complain } & \multirow{2}{*}{$\mathbf{N}$} & \multicolumn{2}{|c|}{ Mean } & Mean & \multirow{2}{*}{ \% Relief } & \multirow{2}{*}{ SD } & \multirow{2}{*}{ SE } & \multirow{2}{*}{ 't' } & \multirow{2}{*}{ P } & \multirow{2}{*}{ Si. } \\
\cline { 3 - 9 } & & $\mathbf{B T}$ & $\mathbf{A T}$ & $\mathbf{d i f f}$ & & & & & & \\
\hline Pain & 14 & 1.267 & 0.000 & 1.267 & $100 \%$ & 0.594 & 0.153 & 8.264 & $<0.001$ & HS \\
\hline Inflammation & 15 & 1.267 & 0.066 & 1.200 & $93.33 \%$ & 0.561 & 0.145 & 8.290 & $<0.001$ & HS \\
\hline Bleeding & 13 & 1.067 & 0.000 & 1.067 & $80 \%$ & 0.799 & 0.206 & 5.172 & $<0.001$ & HS \\
\hline Halitosis & 14 & 1.200 & 0.066 & 1.133 & $90 \%$ & 0.516 & 0.133 & 8.500 & $<0.001$ & HS \\
\hline
\end{tabular}

Table-18: Effect of therapy on Objective criteria Group-A.

\begin{tabular}{|c|c|c|c|c|c|c|c|c|c|c|}
\hline \multirow{2}{*}{$\begin{array}{c}\text { Objective } \\
\text { criteria }\end{array}$} & \multirow{2}{*}{$\mathbf{N}$} & \multicolumn{2}{|c|}{ Mean } & \multirow{2}{*}{$\begin{array}{c}\text { Mean } \\
\text { Diff. }\end{array}$} & \multirow{2}{*}{$\begin{array}{c}\% \\
\text { Relief }\end{array}$} & \multirow{2}{*}{ SD } & \multirow{2}{*}{$\mathbf{S E}$} & \multirow{2}{*}{${ }^{\prime} \mathbf{t}^{\prime}$} & \multirow{2}{*}{$\mathbf{P}$} & \multirow{2}{*}{ Si. } \\
\hline & & BT & AT & & & & & & & \\
\hline C.I. & 15 & 1.933 & 0.400 & 1.533 & $80 \%$ & 0.640 & 0.165 & 9.280 & $<0.001$ & HS \\
\hline D.I. & 15 & 2.267 & 0.533 & 1.733 & $73.33 \%$ & 0.961 & 0.248 & 6.985 & $<0.001$ & HS \\
\hline O.H.I. & 15 & 1.800 & 0.333 & 1.467 & $83.33 \%$ & 0.516 & 0.133 & 11.00 & $<0.001$ & HS \\
\hline G.I. & 15 & 1.000 & 0.267 & 0.733 & $66.66 \%$ & 0.799 & 0.206 & 3.556 & $<0.001$ & $\overline{\mathrm{HS}}$ \\
\hline
\end{tabular}


Table-19: Effect of therapy on Objective criteria Group-B.

\begin{tabular}{|c|c|c|c|c|c|c|c|c|c|c|}
\hline \multirow{2}{*}{$\begin{array}{c}\text { Objective } \\
\text { Criteria }\end{array}$} & \multirow{2}{*}{$\mathbf{N}$} & \multicolumn{2}{|c|}{ Mean } & \multirow{2}{*}{$\begin{array}{c}\text { Mean } \\
\text { Diff. }\end{array}$} & \multirow{2}{*}{$\begin{array}{c}\% \\
\text { Relief }\end{array}$} & \multirow{2}{*}{ S.D. } & \multirow{2}{*}{ S.E. } & \multirow{2}{*}{${ }^{\prime} \mathbf{t}^{\prime}$} & \multirow{2}{*}{$\mathbf{P}$} & \multirow{2}{*}{$\mathbf{S i}$} \\
\hline & & BT & AT & & & & & & & \\
\hline C.I. & 15 & 2.467 & 0.000 & 2.467 & $100 \%$ & 0.516 & 0.133 & 18.50 & $<0.001$ & HS \\
\hline D.I. & 15 & 2.267 & 0.067 & 2.200 & $96.66 \%$ & 0.561 & 0.145 & 15.19 & $<0.001$ & HS \\
\hline O.H.I. & 15 & 1.667 & 0.000 & 1.667 & $100 \%$ & 0.816 & 0.211 & 7.906 & $<0.001$ & HS \\
\hline G.I. & 15 & 1.267 & 0.066 & 1.200 & $93.33 \%$ & 0.561 & 0.145 & 8.290 & $<0.001$ & HS \\
\hline
\end{tabular}

Table-20: Comparison of effect of therapy on subjective criteria.

\begin{tabular}{|c|c|c|c|c|c|c|c|c|c|c|c|c|}
\hline \multirow{2}{*}{$\begin{array}{l}\text { Chief } \\
\text { com- } \\
\text { plains }\end{array}$} & \multirow{2}{*}{$\begin{array}{l}\mathbf{N} \\
\mathbf{A}\end{array}$} & \multirow{2}{*}{$\begin{array}{l}\mathbf{N} \\
\mathbf{B}\end{array}$} & \multirow{2}{*}{$\begin{array}{c}\text { Mea } \\
\text { n } \\
\text { Diff. } \\
\text { G-A }\end{array}$} & \multirow{2}{*}{$\begin{array}{c}\text { Mea } \\
\text { n } \\
\text { Diff. } \\
\text { G-B }\end{array}$} & \multirow{2}{*}{$\begin{array}{c}\text { Mea } \\
\text { n } \\
\text { Diff. }\end{array}$} & \multicolumn{2}{|c|}{$\mathbf{S D} \pm$} & \multicolumn{2}{|c|}{$\mathbf{S E} \pm$} & \multirow[b]{2}{*}{ ' $\mathbf{t}$ ' } & \multirow[b]{2}{*}{$\mathbf{P}$} & \multirow[b]{2}{*}{ Si. } \\
\hline & & & & & & $\mathbf{A}$ & B & $\mathbf{A}$ & B & & & \\
\hline Pain & 9 & 14 & 1.111 & 1.357 & $\overline{0} .246$ & $\begin{array}{l}0.78 \\
2\end{array}$ & 0.497 & 0.261 & $\begin{array}{l}0.13 \\
3\end{array}$ & $-\overline{0.927}$ & 0.364 & IS \\
\hline $\begin{array}{l}\text { Inflamma- } \\
\text { tion of } \\
\text { gums }\end{array}$ & $\begin{array}{l}1 \\
5\end{array}$ & 15 & 1.133 & 1.200 & $\overline{0} .066$ & $\begin{array}{l}0.74 \\
3\end{array}$ & 0.561 & 0.192 & $\begin{array}{l}0.19 \\
2\end{array}$ & $-\overline{0.277}$ & 0.784 & IS \\
\hline Bleeding & $\begin{array}{l}1 \\
0\end{array}$ & 13 & 1.000 & 1.231 & $\overline{0} .231$ & $\begin{array}{l}0.47 \\
1\end{array}$ & 0.725 & 0.149 & $\begin{array}{l}0.14 \\
9\end{array}$ & $\overline{0}-872$ & 0.393 & IS \\
\hline Halitosis & $\begin{array}{l}1 \\
3\end{array}$ & 14 & 1.462 & 1.214 & 0.247 & $\begin{array}{l}0.66 \\
0\end{array}$ & 0.426 & 0.183 & $\begin{array}{l}0.18 \\
3\end{array}$ & 1.165 & 0.255 & IS \\
\hline
\end{tabular}

Table-21: Comparison of effect of therapy on subjective criteria.

\begin{tabular}{|c|c|c|c|c|c|c|c|c|c|c|c|c|}
\hline \multirow{2}{*}{$\begin{array}{l}\text { Objecti } \\
\text { ve } \\
\text { Criteria }\end{array}$} & \multirow{2}{*}{$\begin{array}{l}\mathbf{N} \\
\mathbf{A}\end{array}$} & \multirow{2}{*}{$\begin{array}{l}\mathbf{N} \\
\mathbf{B}\end{array}$} & \multirow{2}{*}{$\begin{array}{c}\text { Mean } \\
\text { Diff. } \\
\text { G-A }\end{array}$} & \multirow{2}{*}{$\begin{array}{l}\text { Mean } \\
\text { Diff. } \\
\text { G-B }\end{array}$} & \multirow{2}{*}{$\begin{array}{c}\text { Mean } \\
\text { Diff. }\end{array}$} & \multicolumn{2}{|c|}{$\mathbf{S D} \pm$} & \multicolumn{2}{|c|}{$\mathbf{S E} \pm$} & \multirow{2}{*}{ ' $t$ ' } & & \multirow{2}{*}{ Si. } \\
\hline & & & & & & A & B & A & B & & & \\
\hline C.I. & 15 & 15 & 1.530 & 2.460 & -0.933 & 0.640 & 0.516 & 0.165 & 0.133 & -0.439 & $<0.001$ & HS \\
\hline D.I. & 15 & 15 & 1.733 & 2200 & -0.467 & 0.961 & 0.561 & 0.248 & 0.145 & -1.624 & 0.116 & IS \\
\hline O.H.I & 15 & 15 & 1.467 & 1.667 & -0.200 & 0.516 & 0.816 & 0.133 & 0.211 & -0.802 & 0.429 & IS \\
\hline G.I. & 15 & 15 & 1.000 & 1.200 & -0.200 & 0.775 & 0.561 & 0.234 & 0.145 & -0.765 & 0.452 & IS \\
\hline
\end{tabular}

Table-22: Overall assessment of therapy of therapy Group-A and Group- B.

\begin{tabular}{|l|c|c|c|c|}
\hline \multirow{2}{*}{ Result } & \multicolumn{2}{|c|}{ Group-A } & \multicolumn{2}{c|}{ Group- B } \\
\cline { 2 - 5 } & No. of patients & $\%$ & No. of patients & $\%$ \\
\hline Cured & 0 & $0 \%$ & 9 & $60 \%$ \\
\hline Marked Improvement & 6 & $40 \%$ & 5 & $33.33 \%$ \\
\hline Moderate Improvement & 6 & $40 \%$ & 1 & $6.66 \%$ \\
\hline Mild Improvement & 2 & $13.33 \%$ & 0 & $0 \%$ \\
\hline Unchanged & 1 & $6.66 \%$ & 0 & $0 \%$ \\
\hline Total & 15 & $100 \%$ & 15 & $100 \%$ \\
\hline
\end{tabular}


Table-23: Feedback

\begin{tabular}{|c|l|c|c|}
\hline No. & \multicolumn{1}{|c|}{ Questions } & $\begin{array}{c}\text { Dantashodhana } \\
\text { paste }\end{array}$ & $\begin{array}{c}\text { Dantashodhana } \\
\text { Choorna }\end{array}$ \\
\hline 1 & Freshness & $85 \%$ & $15 \%$ \\
\hline 2 & Color & $80 \%$ & $20 \%$ \\
\hline 3 & Taste & $75 \%$ & $25 \%$ \\
\hline 4 & More time consuming & $15 \%$ & $85 \%$ \\
\hline 5 & Comfortable and easy & $85 \%$ & $15 \%$ \\
\hline 6 & More Satisfactory & $80 \%$ & $20 \%$ \\
\hline 7 & Stable in use \& storage & $90 \%$ & $10 \%$ \\
\hline 8 & Pref. for longer period use & $80 \%$ & $20 \%$ \\
\hline 9 & Regular use & $75 \%$ & $25 \%$ \\
\hline 10 & Use in diseased condition & $70 \%$ & $30 \%$ \\
\hline 11 & Dispense to other people & $85 \%$ & $15 \%$ \\
\hline 12 & First preference b/w two & $75 \%$ & $25 \%$ \\
\hline 13 & Preference in comparison to an older drug. & $80 \%$ & $20 \%$ \\
\hline
\end{tabular}

Figure:1 Comparison of effect of therapy of Subjective Criteria

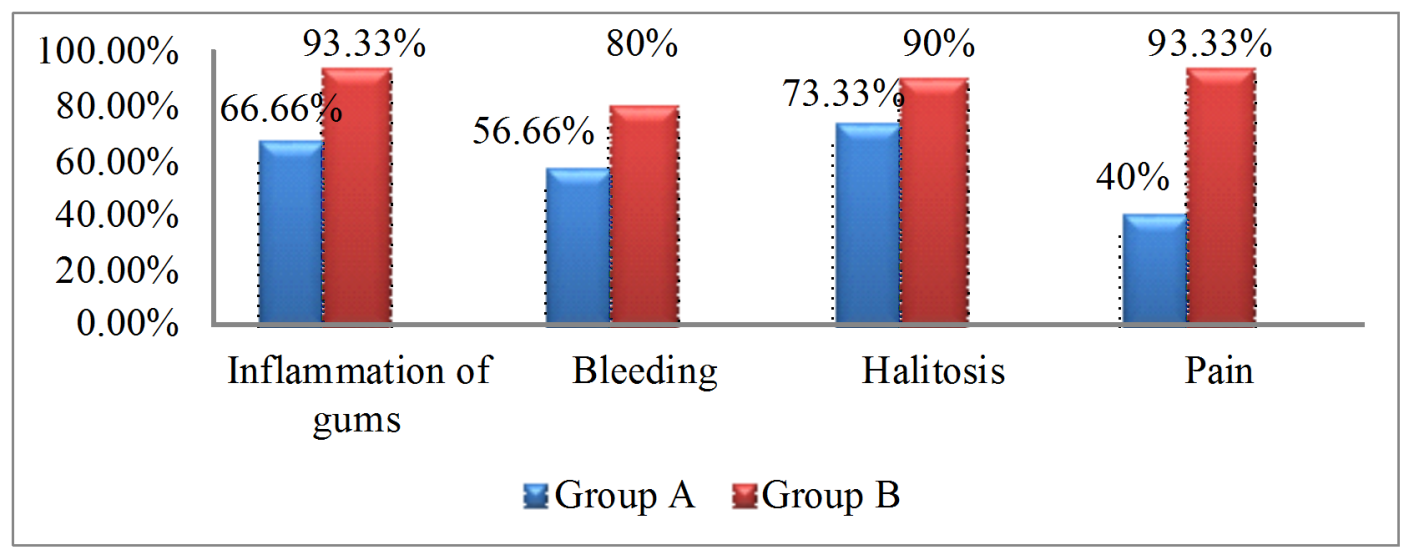

Figure:2 Comparison of effect of therapy of Objective Criteria

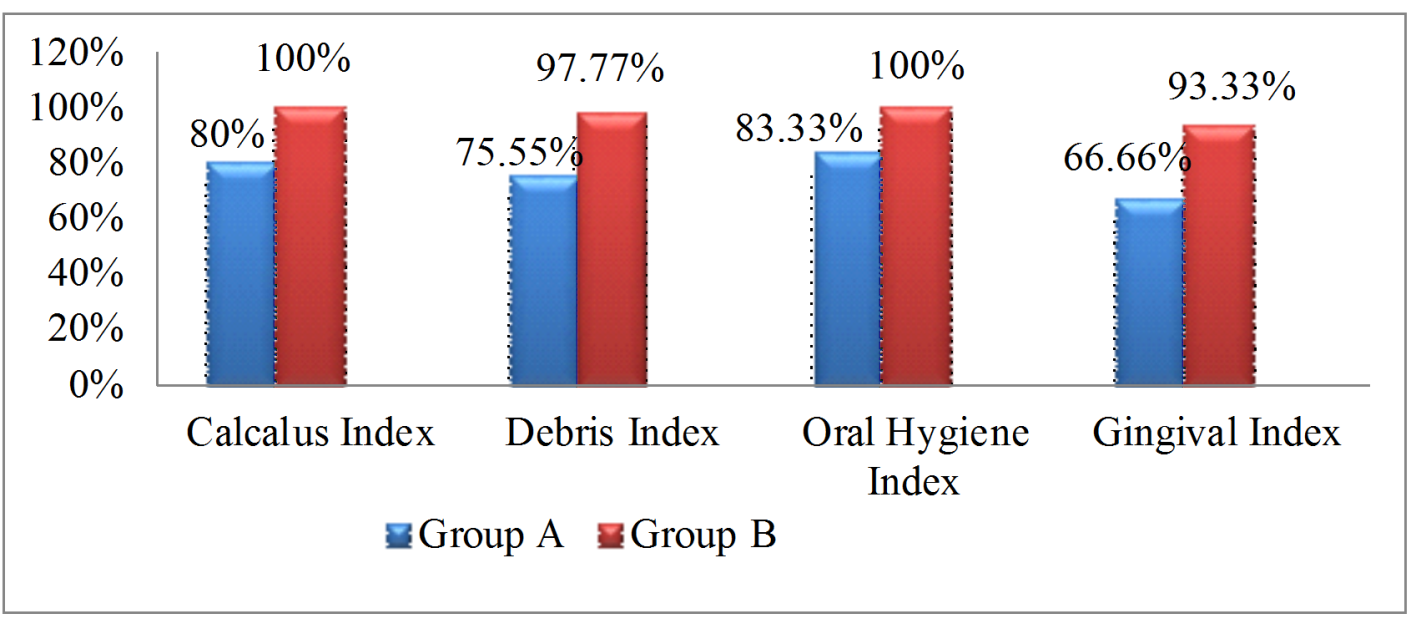




\section{Figure 3: Overall effect of therapy}

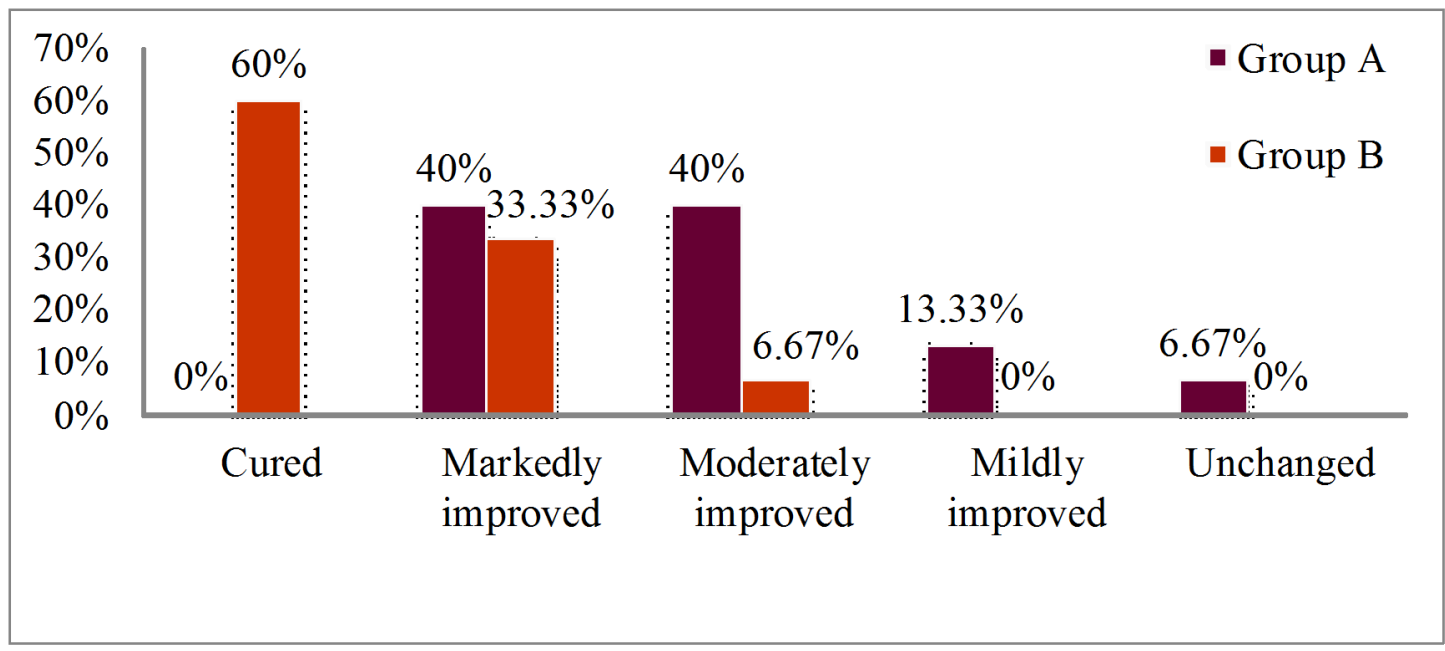

Figure-4: Before scaling \& after scaling
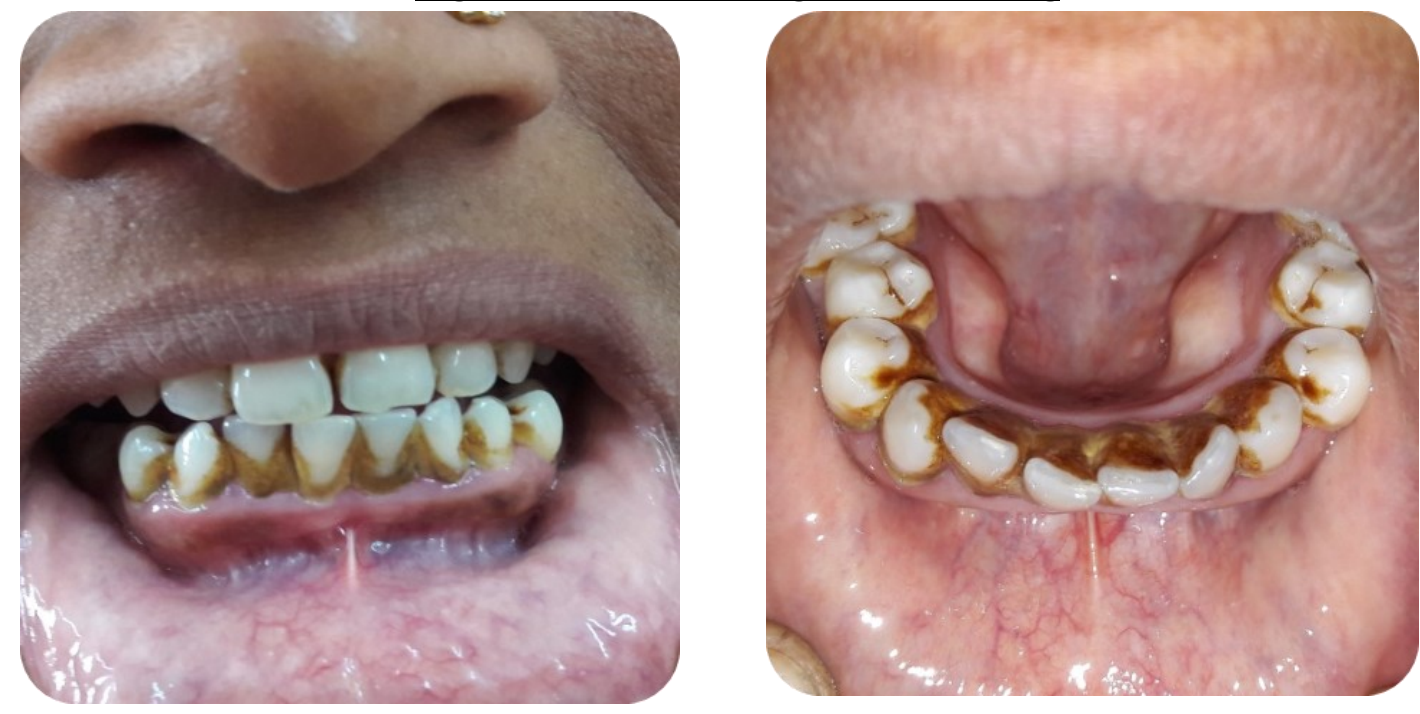

Calculus deposition at lower anterior teeth
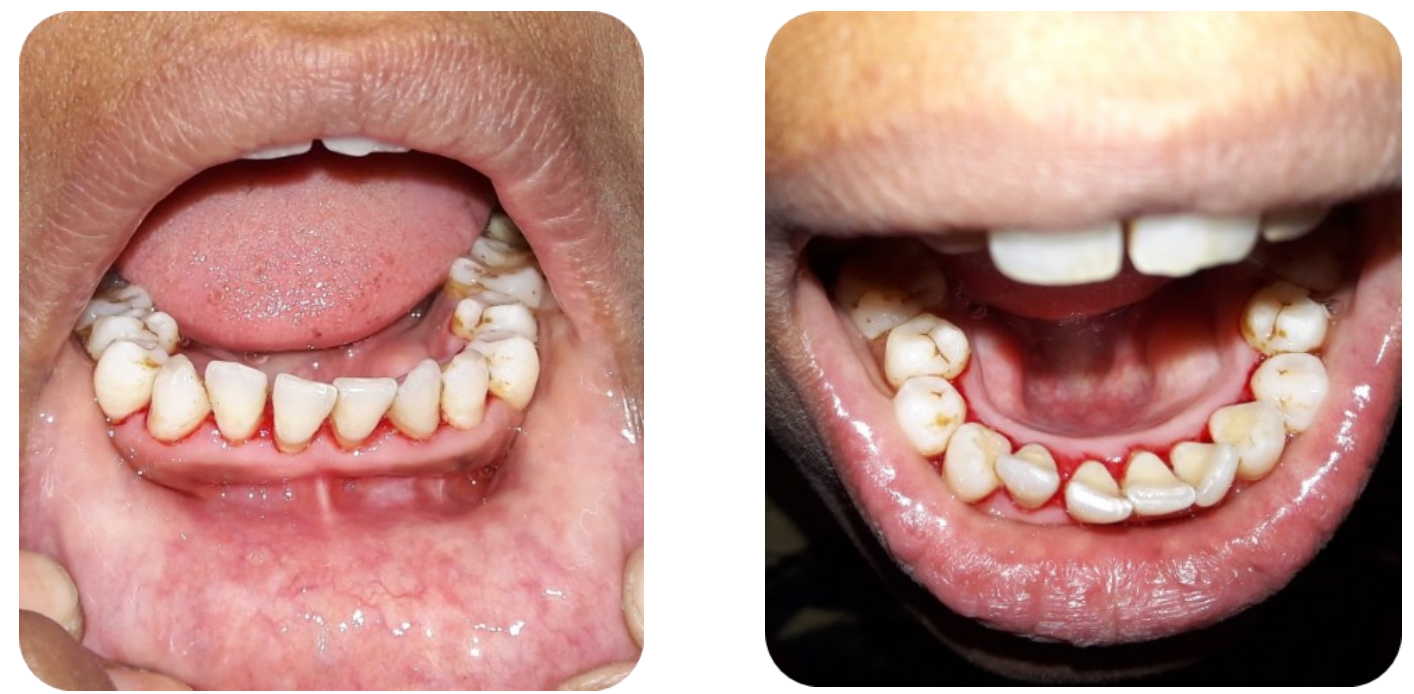

Calculus Removed 


\section{References:}

1. Sushruta, Sushruta Samhita with dalhan tika by vaidya Yadavji trikamji acharya, Ed. Chaukhambha Surbharati prakashan, Varanasi, 2008, chikitsa chapter $40 / 69$, page no. 792

2. Sushruta, Sushruta Samhita with dalhan tika by vaidya Yadavji trikamji acharya, Ed. Chaukhambha Surbharati prakashan, Varanasi, 2008, Nidana sthana chapter $16 / 3$, page no. 420

3. Sushruta, Sushruta Samhita with dalhan tika by vaidya Yadavji trikamji acharya, Ed. Chaukhambha Surbharati prakashan, Varanasi, 2008, Nidana sthana chapter 16/32-33, page no.425

4. http://dictionary.sensagent.com/Calculus, $\%$ 20Dental/en-en

5. http://www.juniordentist.com/crystal-forms-incalculus-supragingival-and-subgingivalcalculus.html/comment-page-1

6. http://periobasics.com/dental-calculus-its-role-inpathogenesis-of-periodontal-diseases.html

7. Carranza's Clinical Periodontology, Chap - 10, Page No. 170-176

8. JADA Vol.126, May 1995

9. http://www.joponline.org/doi/abs/10.1902/ jop.1998.69.9.955

10. Carranza's Clinical Periodontology, Chap - 10, pp. 176

11. Sushruta, Sushruta Samhita with dalhan tika by vaidya Yadavji trikamji charya, Ed. Chaukhambha
Surbharati prakashan, Varanasi, 2008, Chikitsasthana chapter 24/7-8-9, pp.322

12. Suresh Kumar et. al., pharmacological and Cinnamomum tamala, JPR 2012, 5(1), 480-484.

13. T. P. Singh, O. M. Singh, Phytochemical and pharmacological profile....Zanthozylum armatum, IJNPR Vol. 2(3), Sept. 2011, pp 275-285.

14. Agnivesh, Charaka Samhita revised by Charaka and Driddhabala with Ayurveda Dipika commentary, by Chakrapanidata, edited by Vaidya Yadavaji Trikamaji Acharya, Krishnadas Academy, Gopal Mandir Lane, Varanasi, India, Reprint 2000, Sutrasthana, Chapter 26/30, pp. 143

15. Agnivesh, Charaka Samhita revised by Charaka and Driddhabala with Ayurveda Dipika commentary, by Chakrapanidata, edited by Vaidya Yadavaji Trikamaji Acharya, Krishnadas Academy, Gopal Mandir Lane, Varanasi, India, Reprint 2000, Sutrasthana, Chapter 27/300, pp. 213

16. Sushruta, Sushruta Samhita with dalhan tika by vaidya Yadavji trikamji charya, Ed. Chaukhambha Surbharati prakashan, Varanasi, 2008, Chikitsasthana chapter 26/314, pp.3812

17. Sushruta, Sushruta Samhita with dalhan tika by vaidya Yadavji trikamji acharya, Ed. Chaukhambha Surbharati prakashan, Varanasi, 2008, chikitsa Sthana chapter 24/9-11, page no. 338 